\title{
KEGAGALAN AKUNTANSI DALAM MENANGGULANGI FRAUD (PERSPEKTIF POSTMODERN)
}

\author{
Anantawikrama Tungga Atmadja \\ Universitas Pendidikan Ganesha \\ anantawikrama_t_atmadja@undiksha.ac.id \\ Komang Adi Kurniawan Saputra \\ Fakultas Ekonomi Universitas Warmadewa \\ komangadikurniawan@gmail.com
}

\begin{abstract}
Fraud often cannot be eliminated in the operational activities of the organization, including in the public sector organizations. In a sense, the accounting system applied cannot prevent fraud as idealized. This condition shows that accounting as a narrative cannot be separated from the application of other narratives adopted by humans as accounting agents. This paper will discuss how accounting, including internal control within it, is understood as a narrative in the frame of postmodernism. As a narrative, accounting must compete with other narratives to become a habitus and give a disposition to act on the agent who adheres to it. Humans, as accountants, must also be positioned as complex creatures and not only moved on the basis of mere rationality. This understanding is expected to provide a more holistic understanding of the background of the failure and success of accounting in overcoming fraud and suggestions for corrective actions.
\end{abstract}

\section{Keywords: fraud, narration, postmodernism, habitus}

\begin{abstract}
Abstrak
Fraud seringkali tidak dapat dihilangkan dalam aktivitas operasioanal organisasi, termasuk pada organisasasi sektor publik. Kondisi ini sedikit banyak menunjukkan bahwa sistem akuntansi yang diterapkan tidak dapat mencegah terjadinya fraud sebagaimana yang diidealkan. Kondisi ini menunjukkan akuntansi sebagai sebuah narasi tidak dapat dipisahkan penerapannya dari narasi lain yang dianut oleh manusia sebagai pelaku akuntansi. Makalah ini akan membahas bagaimana akuntansi, termasuk pengendalian internal di dalamnya, dipahami sebagai sebuah narasi dalam bingkai posmodernisme.
\end{abstract}


Sebagai sebuah narasi, akuntansi haruslah berkompetisi dengan narasi lainnya untuk menjadi habitus dan memberikan disposisi bertindak kepada agen yang menganutnya. Manusia, sebagai pelaku akuntansi, juga harus diposisikan sebagai makhluk yang kompleks dan tidak bergerak atas dasar rasionalitas semata.Pemahaman ini diharapkan dapat memberikan pemahaman yang lebih holistik tentang latar belakang kegagalan maupun keberhasilan akuntansi dalam menanggulangi fraud berikut saran tindak perbaikannya.

\section{Kata kunci: fraud, narasi, posmodernisme, habitus}

\section{PENDAHULUAN}

Fraud memiliki definisi yang luas serta akar sejarah yang panjang. Sebagaimana yang dikemukakan oleh Priantara (2013: 4), fraud adalah, "suatu perbuatan sengaja untuk menipu atau membohongi, suatu tipu daya atau caracara yang tidak jujur untuk mengambil atau menghilangkan uang, harta, hak yang sah milik orang lain baik karena suatu tindakan atau dampak yang fatal dari tindakan itu sendiri". Dalam perspektif sejarah fraud memiliki jejak yang sangat panjang. Brouck dan Boutin (2012) menyatakan bahwa fraud telah menjadi permasalahan sejak jaman Yunani kuno bahkan kitab-kitab suci berbagai agama juga memberikan perhatian kepada tindakan fraud sebagai perbuatan jahat yang harus dihindari.

Dalam disiplin akuntansi, upaya pencegahan terjadinya fraud juga mendapat perhatian yang besar dan ditunjukkan dengan adanya kewajiban manajemen dalam melaksanakan pengendalian internal dalam entitas bisnis yang dikelolanya (Arens, Elder dan Beasley, 2013). Pengendalian internal yang 
memadai akan dapat menjamin terciptanya reliabilitas pelaporan keuangan, efesiensi dan efektivitas operasional, dan ketaatan terhadap hokum serta peraturan. Dengan kata lain, jika pengendalian internal telah dilaksanakan dengan baik maka dapat dipastikan terjadinya fraud dalam sebuah organisasi dapat diminimalisir atau bahkan dihilangkan.

Pengendalian internal yang memadai dilakukan dengan memperhatikan lima unsur pengendalian yakni: 1) lingkungan pengendalian, 2) penaksiran resiko, 3) aktivitaspengendalian, 4) informasi dan komunikasi, dan 5) pemantauan (Arens, Elder dan Beasley, 2013). Masing-masing komponen tersebut dapat dijelaskan sebagai berikut:

(1) Lingkungan pengendalian (control environment) menetapkan corak suatu organisasi, mempengaruhi kesadaran pengendalian orang-orangnya. Lingkungan pengendalian merupakan dasar untuk semua komponen pengendalian intern, menyediakan disiplin dan struktur. Lingkungan pengendalian mencakup Integritas (kejujuran) dan nilai etika, komitmen terhadap kompetensi, partisipasi dewan komisaris, atau komite audit, filosofi dan gaya operasi manajemen, struktur organisasi, pemberian wewenang dan tanggung jawab, kebijakan dan praktik sumber daya manusia. (2) penaksiran resiko (risk assessment) adalah identifikasi entitas dan analisis terhadap resiko yang relevan untuk mencapai tujuannya, membentuk suatu dasar untuk menentukan bagaimana resiko harus dikelola. Resiko dapat timbul atau berubah karena keadaan: perubahan lingkungan operasi, personel baru. Sistem informasi yang baru atau di-enhance, teknologi baru, lini produk, produk atau aktivitas baru, operasional di luar negeri, standard akuntansi atau regulasi baru. (3) aktivitas pengendalian (control activities) adalah kebijakan dan prosedur yang membantu menjamin bahwa arahan manajemen dilaksanakan. Kebijakan dan prosedur yang dimaksud berkaitan dengan penelaahan terhadap kinerja, pengolaha informasi, pengendalian fisik, pemisahan tugas dan fungsi. (4) Informasi dan komunikasi 
Anantawikrama Tungga A. E Komang Adi K. S. : Kegagalan Akuntansi dalam....

(information and communication) adalah identifikasi adalah identifikasi, pengumpulan dan pertukaran informasi dalam suatu bentuk yang memungkinkan orang melaksanakan tanggung jawab mereka secara efektif. Sistem akuntansi memungkinkan orang melaksanakan tanggung jawab mereka secara efektif. Sistem informasi mencakup sistem akuntansi.Komunikasi mencakup penyediaan suatu pemahaman tentang peran dan tanggung jawab individual berkaitan dengan pengendalian intern terhadap pelaporan keuangan.(5) Pemantauan (monitoring) adalah proses memastikan mutu, kinerja dan pengendalian intern sepanjang waktu. Pemantauan mencakup tindakan koreksi (Priantara, 2013: 197-198)

Berdasarkan paparan tersebut dapat dipahami bahwa pengendalian intern memiliki cakupan yang sedemikian luas. Dia tidak hanya terkait aspek teknis operasional organisasi namun juga mencakup aspek nilai yang menjunjung tinggi etika moral.Kondisi ini membuat pengendalian internal juga mengatur manusia sebagai pelaku akuntansi. Dengan kata lain, pengendalian internal berbasis akuntansi merupakan resep bertindak atau apa yang disebut oleh Bordieu sebagai habitus yang dapat memberikan disposisi kepada agen dalam bertindak (Takwim, 2005).

Meskipun memiliki ruang lingkup yang luas, namun pengendalian internal akuntansi tidak secara otomatis dapat menghindarkan terjadinya fraud. Hal ini dapat ditunjukkan dengan masih maraknya fraud dalam berbagai bentuk yang terjadi baik pada institusi swasta maupun pemerintahan. Bahkan korupsi sebagai salah satu bentuk fraud masih menjadi musuh utama masyarakat 
Indonesia dan mendorong lahirnya Komisi Pemberantasan Korupsi (KPK) yang khusus menangani kasus-kasus korupsi.

Kegagalan pengendalian internal menujukkan bahwa ilmu akuntasi beserta praktik-praktik sosial yang berbasis ilmu akuntansi tidak dapat menghindarkan organisasi dari terjadinya fraud. Hal ini disebabkan dalam prateknya akuntansi bukanlah satu-satunya narasi yang dijadikan resep bertindak yang dianut oleh seorang agen dan senantiasa berdialektik dengan narasi-narasi lainnya.Makalah ini akan membahas bagaimana akuntansi, termasuk pengendalian internal di dalamnya, dipahami sebagai sebuah narasi dalam bingkai posmodernisme.Sebagai sebuah narasi, akuntansi haruslah berkompetisi dengan narasi lainnya untuk menjadi habitus dan memberikan disposisi bertindak kepada agen yang menganutnya.Manusia, sebagai pelaku akuntansi, juga harus diposisikan sebagai makhluk yang kompleks dan tidak bergerak atas dasar rasionalitas semata.Pemahaman ini diharapkan dapat memberikan pemahaman yang lebih holistik tentang latar belakang kegagalan maupun keberhasilan akuntansi dalam menanggulangi fraud berikut saran tindak perbaikannya. 
Anantawikrama Tungga A. E Komang Adi K. S. : Kegagalan Akuntansi dalam....

\section{TELAAH LITERATUR}

\section{Fraud}

Fraud diterjemahkan sebagai penyimpangan, demikian pula dengan error dan irregularities masing-masing diterjemahkan sebagai kekeliruan dan ketidakberesan (Dewi dan Apandi, 2012). Sedangkan SAS No.99 (dalam Rustiarini dan Sunarsih, 2015) mendefinisikan kecurangan sebagai tindakan kesengajaan untuk menghasilkan salah saji material dalam laporan keuangan. Perbedaan dari penyimpangan dan kekeliruan adalah apakah tindakan yang mendasarinya, apakah tindakan tersebut merupakan tindakan yang disengaja atau tidak. Fraud atau penyimpangan dilakukan dengan unsur kesengajaan dalam melakukannya. ACFE's mendefinisikan fraud sebagai tindakan mengambil keuntungan secara sengaja dengan cara menyalahgunakan suatu pekerjaan/jabatan atau mencuri asset/sumberdaya dalam organisasi (Singleton \& Singleton, 2010).

Fraud atau kecurangan adalah objek utama yang diperangi dalam akuntansi forensik. Kecurangan adalah suatu pengertian umum yang mencakup beragam cara yang dapat digunakan oleh kecerdikan manusia, yang digunakan oleh seseorang untuk mendapatkan keuntungan dari orang lain melalui perbuatan yang tidak benar. Kecurangan adalah penipuan yang disengaja, umumnya dalam bentuk kebohongan, penjiplakan dan pencurian. 
Kecurangan dilakukan untuk memperoleh keuntungan berupa uang dan kekayaan, atau untuk menghindari pembayaran atau kerugian jasa, atau menghindari pajak serta mengamankan kepentingan pribadi atau usaha.

\section{PEMBAHASAN}

Sebagaimana yang dikemukakan oleh Muhlisin (2000), posmodernisme merupakan sebuah pemikiran yang menggantikan pemikiran modernisme yang mengakui adanya satu kebenaran tunggal yang berlaku secara universal.Kebenaran, atau sering pula disebut sebagai narasi, sangatlah beragam dan memberikan pengaruh kepada setiap aktor yang menganutnya.Dengan demikian, akuntansi yang dipahami oleh pelakunya hanyalah salah satu dari beragam narasi yang dimiliki oleh aktor yang bersangkutan.

Dengan mengacu kepada gagasan Piliang (2011), Akuntansi dapat digolongkan adalah narasi besar atau menurut Lyotard (2009; dalam Gaut, 2011) disebut juga pengetahuan ilmiah, tidak saja karena ilmu akuntasi serta praktik-praktik sosial yang menyertainya berasal dari peradaban Barat, tetapi juga karena memiliki ciri-ciri universal, rasional, sentral dan homogin. Pemberlakuan Ilmu akuntasi dalam suatu lokalitas, mengakibatkan ilmu akuntansi berhadapan dengan narasi kecil atau menurut Lyotard (2009; dalam Gaut, 2011) disebut pengetahuan naratif, berwujud struktur ideasional lokal 
Anantawikrama Tungga A. E Komang Adi K. S. : Kegagalan Akuntansi dalam....

yang terdiri dari ideologi, nilai, norma, dan berbagai bentuk pengetahuan lokal yang secara umum bisa disebut aspek kognitif dan aspek evaluatif (Geertz, 1999) beserta praktik-praktik sosial yang menyertainya. Narasi kecil ini memiliki ciri, yakni heterogin, plural, kontekstual, lokal, unik, dan indigenous yang diwadahi dalam institusi-institusi lokal dalam bentuk berbagai aturan (Piliang, 2008: 173, 2011: 483). Akuntansi sebagai narasi besar beserta keterkaitannya dengan narasi kecil dan individu pelaksananya dapat digambarkan di gambar 1.

Perjumpaan antara tradisi besar dan tradisi kecil, tidak bercorak saling meniadakan yang lainnya, tetapi memunculkan hubungan negosiatif dalam suatu habitus. Habitus ini tidak lagi bercorak universal, rasonal, sentral dan homogin seperti yang berlaku pada tradisi besar, melainkan berbaur dengan karakter yang bersifat heterogin, plural kontekstual, lokal, unik, dan indigenous sebagaimana yang berlaku pada tradisi kecil. Akibatnya, tidak saja terjadi pembauran pada aspek kognisi dan aspek evaluatif, tetapi juga pada praktikpraktik sosial yang berbasis ilmu akuntansi, yakni tidak lagi memiliki konsistensi yang kaku sebagaimana yang digariskan oleh karakternya yang bercorak universal, rasional, sentral dan homogin, melainkan bisa memunculkan inkonsistensi, karena telah diadaptasikan dan atau dilegitimasi oleh tuntutan 
karakteristik narasi kecil, yakni heterogin, plural, kontekstual, lokal, unik, dan indigenous.

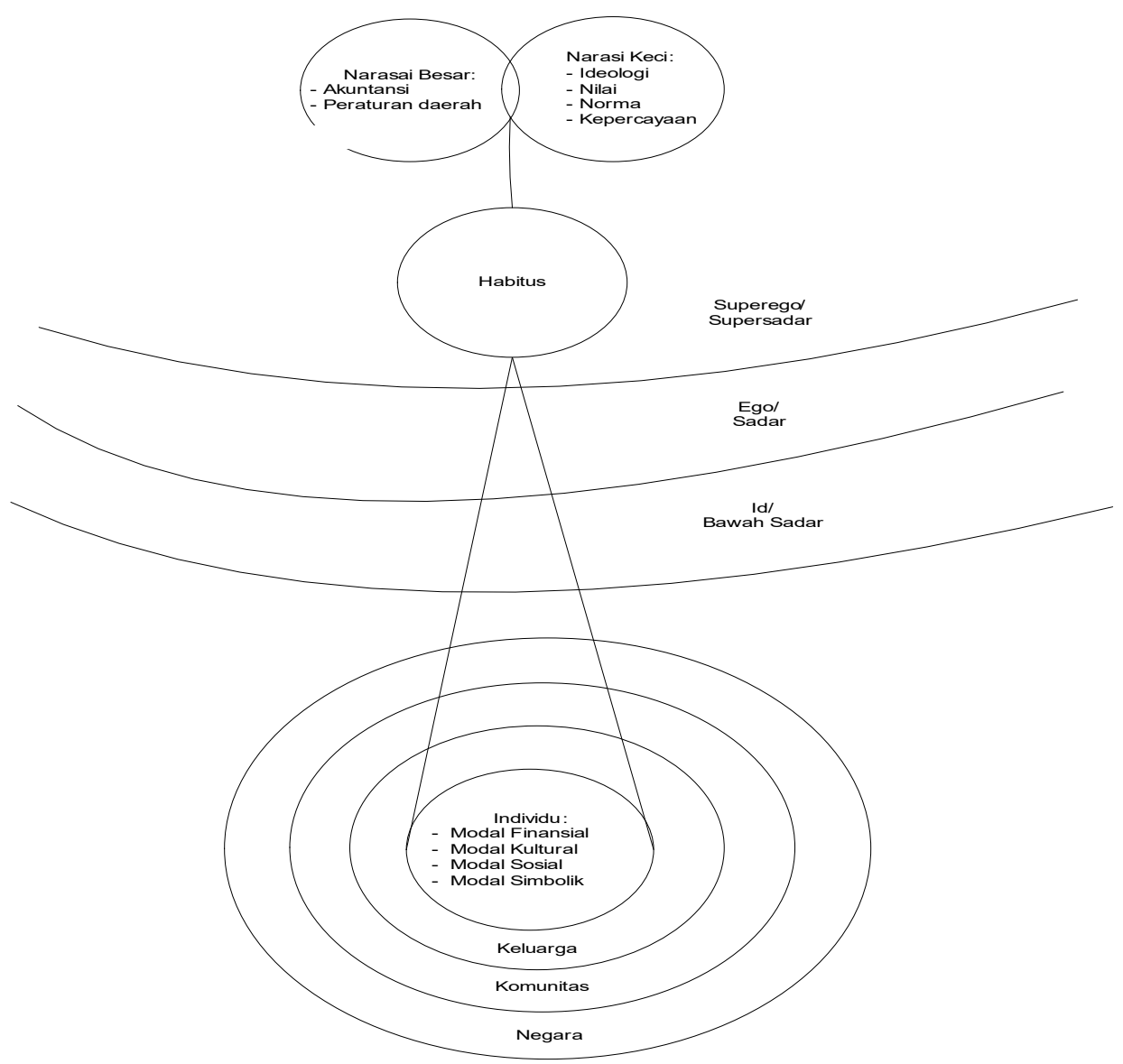

Gambar 1

Posisi Ilmu Akuntasi Sebagai Narasi Besar dan Kaitannya Dengan Narasi Kecil Berserta Komponen-Komponen Lainnya

Pemahaman ini membuat teori-teori dalam ilmu akuntasi tidak bisa diposisikan sebagai hukum-hukum yang dapat memberikan ramalan yang tepat tentang peristiwa yang akan terjadi dalam dimensi ruang dan waktu seperti yang diasumsikan pada paradigma positivistik - meminjam gagasan 
Anantawikrama Tungga A. E Komang Adi K. S. : Kegagalan Akuntansi dalam....

Richardson dan Power (2005) - melainkan hanya sebagai habitus, yakni skemata disposisional sebagaimana diasumsikan pada teori sosial kritis. Dengan berpegang pada paradigma ini maka dapat dijelaskan bahwa penyimpangan dalam praktik-praktik sosial yang berbasis ilmu akuntansi tidak saja merupakan penanda bahwa tata cara yang berbasis ilmu akuntasi tidak bersifat menentukan secara mutlak, tetapi bergantung pada hasil pembacaan dan penginterpretasian secara maknawi, meruang dan mewaktu yang dilakukan oleh agen terhadap teks budaya.

Pembacaan dan penafsiran terhadap praktik akuntansi sebagai teks budaya tidak saja membutuhkan daya kreativitas dengan memakai aneka potensinya sebagai makhluk individu, melainkan secara dekonstruktif seperti terlihat pada Gambar1. bisa diwarnai oleh kepentingan dirinya sendiri beserta keluarganya, pemberlakuan ideologi dominan alam suatu komunitas dan atau negara, yakni ideologi pasar, dan hasrat libidinal dan karnal sesuai dengan hakikat manusia yang selalu terikat pada id atau kama. Dengan demikian tidak mengherankan jika tata aturan yang berbasis ilmu akuntansi, begitu pula tata aturan lainnya sangat berpeluang untuk memunculkan suatu penyimpangan.

Dalam suatu organisasi pengetahuan akuntansi dapat digolongkan sebagai modal kultural. Dengan mengikuti alur pemikiran Foucault (2002, 2007, 2008, 2009) kepemilikan modal kultural termasuk pengetahuan 
akuntansi, memberikan peluang bagi yang bersangkutan untuk memiliki kekuasaan yang lebih besar daripada agen-agen lain pada saat yang bersangkutan bermain pada suatu arena sosial, yakni komunitas. Kondisi ini memberikan peluang bagi terjadinya fraud, sebab, fraud pada dasarnya merupakan penyimpangan dalam penggunaan kekuasaan dengan sasaran memperbesar kepemilikan kapital, terutama kapital finansial yang terkait dengan pemenuhan kepentingan diri sendiri dan keluarga (Binawan, 2006). Dengan demikian, kepemilikan pengetahuan akuntansi tidak saja bermakna positif untuk menghindarkan organisasi dari fraud namun di sisi lain, dapat dijadikan alat bagi pemiliknya untuk melakukan kecurangan.

Gambar 1 menunjukkan bahwa modal kultural hanya merupakan salah satu kapital yang dimiliki agen dalam bermain pada suatu struktur sosial, yakni keluarga, komunitas atau bahkan negara. Dengan mengacu kepada Bourdieu (2010, 2011) selalu bisa terjadi bahwa agen memiliki berbagai kapital lainnya, yakni kapital finansial (ekonomi), sosial, kultur, dan simbolik. Pengakumulasian kepemilikan aneka modal tersebut, tidak saja memberikan peluang bagi seseorang untuk menduduki strata atas dalam struktur sosial, melainkan bisa pula memperkuat dan atau dialihkan menjadi modal kuasa. Dalam kondisi seperti ini maka peluang agen sangat besar untuk memanipulasi tata aturan yang berlaku, termasuk di dalamnya tata aturan akuntansi melalui 
Anantawikrama Tungga A. E Komang Adi K. S. : Kegagalan Akuntansi dalam....

pembentukan wacana, yakni argumentasi sistematik yang memuat beberapa pertimbangan untuk menunjukkan validitas dari sebuah klaim (Littlejohn dan Foss, 2009: 474). Wacana yang terbentuk oleh bahasa bisa menyampaikan realitas atau bisa pula sebaliknya, yakni mendistorsi realitas (Jarvis, 2010). Kesemuanya ini bisa berujung pada pemberian peluang untuk mendapatkan keuntungan finasial yang lebih besar daripada mereka yang memiliki pengakumulasian modal lebih sedikit. Hal ini tidak semata-mata karena ketimpangan kepemilikan modal, tetapi juga karena kepiawainnya membangun wacana. Bahkan yang tidak kalah pentingnya, dengan kepemilikan berbagai modal agen bisa pula bermain secara lebih baik, tidak saja pada tataran komunitas, tetapi juga pada tataran negara sehingga penyimpangan yang dilakukannya menjadi sulit terbongkar, karena tertutupi oleh wacana yang dikemukakannya.

Walaupun tata aturan yang berbasis ilmu akuntansi memiliki legitimasi yang amat kuat karenaberposisi sebagai narasi besar, namun sejauh mana dia mampu mengendalikan tindakan manusia, secara dekonstruktif dapat dikembalikan kepada hakikat manusia. Sebagaimana terlihat pada Gambar 1 dalam perspektif psikoanalisis maka jiwa manusia memiliki tiga aparatus, yakni id, ego, dan super ego (Freud, 2006; dalam Damsir, 2011) atau dalam perspektif filsafat Wedanta disebut alam bawah sadar, alam sadar, dan super 
sadar (Swami, 2005; Suwantana, 2011). Jika id lepas kendali maka manusia akan selalu berusaha memenuhi hasrat (kama) akan libidal dan karnal dengan cara melanggar norma, termasuk di dalamnya tata aturan berbasis ilmu akuntansi. Jika super egomenguasai manusia maka dia akan taat secara kaku pada asas moralitas. Untuk itu, diperlukan faktor penyeimbang, yakni ego atau unsur yang bersifat sadar dan rasional.

Dengan cara ini agen bisa melegitimasi tindakannya secara sadar dan rasional. Bertolak dari gagasan ini maka secara psikoanalisis atau dilihat dari sudut pandang filsafat Wedanta maka dapat dijelaskan bahwa penyimpangan terhadap tata aturan berbasis ilmu akuntansi, begitu pula tata aturan lainnya pada dasarnya merupakan konsekuensi dari hakikat manusia yang bertindak karena didominasi oleh id, kama atau hasrat (libidinal dan karnal) sehingga ego (alam sadar) dan super ego (alam super sadar) terpinggirkan. Gagasan ini memperkuat asumsi bahwa tata aturan berbasis ilmu akuntansi, begitu pula tata aturan lainnya yang membentuk habitus tidak bisa diposisikan sebagai hukum yang mutlak menentukan tindakan manusia dalam struktur sosial. Selain ditentukan oleh berbagai habitus yang dimilikinya tindakan manusia juga merupakan merupakan hasil dari pergolakan antara idatau kama (alam bawah sadar), ego (alam sadar) dan super ego (alam super sadar, asas moralitas, dharma, kebajikan). 
Anantawikrama Tungga A. \& Komang Adi K. S. : Kegagalan Akuntansi dalam....

Terhindar atau terseretnya manusia dalam perilaku menyimpang sangat bergantung pula kepada kontrol sosial. Berger dan Luckmann (1990) menyatakan bahwa tindakan manusia adalah hasil dari konstruksi sosial, yakni dibentuk oleh masyarakat melalui sosialisasi dan kontrol sosial. Sebagaimana terlihat pada Gambar 1 ada tiga lembaga yang memainkan peran penting dalam konteks kontrol sosial eksternal, yakni keluarga, komunitas, dan negara. Jika pengendalian diri seseorang lemah (kontrol sosial internal lemah) maka anasir jahat yang akan muncul. Apalagi dibarengi oleh pembiaran yang dilakukan oleh lembaga yang berkewajiban melakukan kontrol sosial eksternal, maka pelanggaran asas moralitas, apa pun bentuk dan sumbernya, baik agama maupun ilmu akuntasi menjadi tidak terhindarkan.

Gambar 1 menunjukkan bahwa agen sebagai makhluk individu, selain berada dalam suatu habitus, berada pula dalam suatu struktur sosial, mulai dari struktur sosial yang paling kecil, yakni keluarga, terus meluas ke struktur yang lebih besar, yakni komunitas dan negara. Aneka bentuk struktur sosial ini tidak saja merupakan arena sosial untuk mengada atau sesuai dengan hakikat manusia sebagai homo socius, tetapi berfungsi pula sebagai lembaga kontrol sosial eksternal. Namun hakikat manusia tidak saja sebagai makhluk sosial, tetapi juga sebagai makhluk individu. Berkenaan dengan itu manusia pun mengenal dua bentuk kontrol sosial, yakni kontrol sosial eksternal dan kontrol 
sosial internal. Hal ini amat penting, mengingat gagasan Berger $(1985,1987)$ bahwa keberadaan suatu lembaga sosial dengan berbagai tata aturan yang mempedomaninya mutlak membutuhkan kontrol sosial.Kontrol sosial internal berwujud agen mengendalikan dirinya sendiri agar tidak melakukan penyimpangan. Dengan mengikuti gagasan filsafat Wedanta (2005) kontrol sosial internal atau pengendalian diri dilakukan dengan cara mengoptimalkan fungsi-fungsi pikiran (manah), budi (buddhi) dan kesadaran (atman) guna mengendalikan tubuh dan pancaindra. Jika terjadi sebaliknya, yakni tubuh dan pancaindra mengendalikan pikiran, budi, dan kesadaran, maka manusia akan terikat oleh kama atau hasrat sehingga menjadi pribadi yang serakah danberpeluang untuk melakukan penyimpangan amat besar. Kontrol sosial eksternal dilakukan oleh orang atau lembaga di luar sang diri, misalnya keluarga, komunitas, dan negara yang direpresentasikan oleh berbagai lembaga kontrol sosial yang sengaja dibentuk sehingga melahirkan kontrol sosial eksternal bersifat formal. Apa pun bentuk kontrol sosial selalu berkaitan dengan sanksi. Kontrol sosial dan sanksi merupakan satu kesatuan dalam konteks tindakan yang bersifat preventif maupun kuratif agar manusia bertindak secara tepat asas. Dengan berpegang pada gagasan ini maka pemberlakuan tata aturan yang berbasis ilmu akuntansi begitu pula tata aturan lainnya tidak secara otomatis memunculkan ketaatan bagi para agen dalam 
Anantawikrama Tungga A. E Komang Adi K. S. : Kegagalan Akuntansi dalam....

suatu struktur sosial, melainkan membutuhkan pula kontrol sosial, baik kontrol sosial internal maupun eksternal lengkap dengan sanksinya.

\section{Kesimpulan}

Fraud merupakan praktek yang harus diminimalisir bahkan dihilangkan dalam aktivitas operasional organisasi.Akuntansi dengan pengendalian internalnya telah memberikan resep bertindak bagi anggota organisasi dalam mencapai tujuan tersebut.Namun demikian, akuntansi tidak senantiasa berhasil dalam mencegah terjadinya fraud.Sebagai sebuah narasi, akuntansi senantiasa harus "bersaing" denga narasi lainnya untuk dapat menjadi habitus bagi pelaku akuntansi.Permasalahan kemudian muncul ketika narasi lain tersebut tidak mendukung namun malah memperlemah akuntansi.

Manusia sebagai pelaku akuntansi bertindak untuk memenuhi id dengan mempergunakan ego dan dengan pengendalian dari superegonya dengan mempergunakan modal yang dimiliki.Modal tersebut dapat berupa modal finansial, kultural, sosial, dan simbolik. Semakin banyak modal yang dimilikinya maka orang tersebut akan semakin berkuasa sehingga jika disalahgunakan kekuasaan ini dapat dimanfaatkan untuk melakukan perbuatan fraud. Kondisi inilah yang mengakibatkan pengendalian internal dalam diri individu (superego) maupun pengendalian diri eksternal dari diri keluarga, komunita bahkan Negara sangatlah diperlukan. 
Pencegahan terjadinya fraud dapat dilakukan dengan memanfaatkan berbagai narasi yang dapat memperkuat pengendalian intern. Narasi itu dapat berupa nilai, norma ataupun kepercayaan yang dapat mencegah terjadinya penyelewengan. Selain itu pencegahan terhadap terjadinya fraud juga harus dibarengi dengan diperkuatnya pengendalian yang berasal dari dalam maupun luar diri seorang agen.Pengendalian dari dalam diri (kontrol sosial internal) yang dilakukan dengan memposisikan superego sebagai pemegang kendali dengan dalam mempergunakan ego untuk memenuhi id.Jika hal ini mampu dilaksanakan maka dapat dipastikan dalam memenuhi hasratnya manusia senantiasa mengedepankan rasionalitas dengan senantiasa memperhatikan nilai-nilai moralitas.

Pengendalian dari dalam diri agen harus pula diperkuat pengendalian dari luar diri agen (kontrol sosial eksternal). Pendengendalian dari luar diri agen ini dapat berasal dari keluaga, komunitas dan Negara. Pengendalian dari keluarga dapat berasal dari keluarga batih dan keluarga luas.Mereka harus senantiasa melakukan kontrol agar agen tidak melaksanakan tindakan yang tergolong sebagai fraud.Pengendalian diri eksternal juga datang dari komunitas dan negara. Kedua pihak ini dapat menggariksan tata aturan di tingkat komunitas dan negara berikut reward serta punishment-nya yang dapat mengawasi dan mencegah terjadinya fraud. Dengan adanya kontrol sosial eksternal ini 
Anantawikrama Tungga A. \& Komang Adi K. S. : Kegagalan Akuntansi dalam....

diharapkan dapat memperkuat kontrol sosial internal yang sudah dimiliki oleh masing-masing individu sehingga terjadinya fraud semakin dapat dihidari.

\section{REFERENSI}

Arens, AA, R.J Elder, dan M.S Beasley. 2013. Auditing \& Jasa Assurance. [Penerjemah: Tim Penerjemah]. Jakarta: Penerbit Erlangga.

Berger, P. L. 1985. Humanisme Sosiologi. [Penerjemah: Daniel Dhakidae]. Jakarta: Inti Sarana Aksara.

Berger, P.L. 1987. "The Meaning of Social Controls". Dalam Charon (ed.). The Meaning of Sociology A Reader. Halaman: 242-246. New Jersey: Prentice Hall.

Berger, P. L. dan T. Luckman. 1990. Tafsir Sosial atas Kenyataan Risalah tentang Sosiologi. [Penerjemah: Hasan Basari]. Jakarta: LP3ES.

Binawan, A. A. L. 2006. "Korupsi (dalam Cakrawala) Kemanusiaan Beberapa Pernik Gagasan untuk Pengantar". Dalam A. A. L. Binawan (ed). Korupsi Kemanusiaan Menafsirkan Korupsi (dalam) Masyarakat. Jakarta: Kompas. Halaman: xii-xxvi.

Bourdieu, P. 2010. Arena Produksi Kultural Sebuah Kajian Sosiologi Budaya. [Penerjemah: Yudi Santosa]. Yogyakarta: Kreasi Wacana. 
Bourdieu, P. 2011. Choses Dites Uraian dan Pemikiran. [Penerjemah: N. R. Sjams]. Yogyakarta: Kreasi Wacana.

Brock, W dan M. Boutin. 2012. Fraud: History, Issues, Tools and Challenges. Diakses melalui https://www.dwpv.com/Sites/academy/PDFs/Fall2012/Davies-AcademyNovember-06-2012.pdf. Pada tanggal 10 November 2017.

Damsar. 2011. Pengantar Sosiologi Pendidikan. Jakarta: Kencana.

Foucault, M. 2002. Arkeologi Pengetahuan. [Penerjemah: M. Zoerni]. Yogyakarta: Penerbit Qalam.

Foucault, M. 2007. Order of Thing. Arkeologi Ilmu-ilmu Kemanusiaan. [Penerjemah: Priambodo dan Pradana Boy]. Yogyakarta: Pustaka Pelajar. Foucault, M. 2008. Ingin Tahu Sejarah Seksualitas. [Penerjemah: Rahayu S. Hidayat]. Jakarta: Yayasan Obor Indonesia.

Foucault, M. 2009. Pengetahuan dan Metode: Karya-karya penting Foulcaut. [Penerjemah: Arief]. Yogyakarta: Jalasutra.

Freud, S. 2006. Pengantar Umum Psikoanalisis. [Penerjemah: Haris Setiowati]. Yogyakarta: Pustaka Pelajar.

Gault, W. 2011. Filsafat Post Modernisme Jean-François Lyotard. Maumere: Ladalero. 
Anantawikrama Tungga A. \& Komang Adi K. S. : Kegagalan Akuntansi dalam....

Geertz, C. 1999. After The Fact; Dua Negeri; Empat Dasawarsa, Satu Antropolog [Penerjemah: Landung Simatupang]. Yogyakarta: LKiS.

Jarvis. M. 2000. Teori-teori Psikologi Pendekatan Modern untuk Memahami Perilaku, Perasaan dan Pikiran Manusia. [Penerjemah: Tim Penerjemah SPA]. Bandung: Nusa Media.

Littlejohn, S. W. dan K. A. Foss. 2009. Teori Komunikasi. [Penerjemah: M. Y. Hamdan]. Jakarta: Salemba Humanika.

Lyotard, J. 2009. Kondisi Posmodern: Suatu Laporan Mengenai Pengetahuan. [Penerjemah: D. V. Ellyati]. Surabaya: Selasar.

Muhlisin. 2000. "Posmodernisme dan Kritik Ideologi Ilmu Pengetahuan Modern". Okara II. Halaman: 1-20.

Piliang, Y. A. 2011. Dunia yang Dilipat: Tamasya Melampaui Batas-batas Kebudayaan. Bandung: Matahari.

Priantara, D. 2013. Fraud Auditing \& Investigation. Bogor: Mitra Wacana Media Richardson, F. C dan B. J. Powers. 2005. "Teori Kritis, Posmodernisme, dan Hermeneutika Wawasan untuk Psikologi Kritis". Dalam I. Prilleltensky dan D. Fox (ed.). Psikologi Kritis Metaanalisis Psikologi Modern. Bandung: Mizan. Halaman: 55-90. 
Saputra, K.A.K., E. Sujana., dan G.M. Tama. (2018). Perspektif Budaya Lokal Tri Hita Karana dalam Pencegahan Kecurangan pada Pengelolaan Dana Desa. Jurnal Akuntansi Publik, Vol.1, No.1, 2018

Saputra, Komang Adi Kurniawan., Putu Budi Anggiriawan., dan I Nyoman Sutapa. (2018). Akuntabilitas Pengelolaan Keuangan Desa Dalam Perspektif Budaya Tri Hita Karana. Jurnal Riset Akuntansi dan Bisnis Airlangga, Vol. 3. No. 1 (2018) 306-321.

Suwantana, I. G. 2011. Petikan Dawai Wedanta(Indra Udayana Vicharamritam2). Denpasar: Ashram Gandhi Puri.

Swami, B. D. 2005. Seri Vedanta dan Sains Kehidupan dan Asal Mula Jagat Raya. [Penerjemah I. Ngrh. Pranawa]. Denpasar: Sampradaya Kesadaran Krishna Indonesia. 